\title{
Anticancer effect of black tea extract in human cancer cell lines
}

\author{
Katarína Koňariková', Miriam Ježovičová', Ján Keresteš², Helena Gbelcová ${ }^{3}$, Zdeňka Ďuračková and Ingrid Žitňanová ${ }^{*}$
}

\begin{abstract}
In this study we investigated effects of natural extract from the black tea Camellia sinensis (BTE) against human colon carcinoma cell line HT-29, human breast carcinoma cell line MCF-7, human alveolar carcinoma cell line A549 and healthy cell line NIH-3T3. We identified concentration range for cytotoxic/antiproliferative effects using MTT assay and the trypan blue assay, gel electrophoresis we employed to determine the type of cell death induced by BTE and DNA damage we determined by comet assay. Different concentrations of the extract $(0.00078-5 \mu \mathrm{g} / \mathrm{mL})$ we added to the cultured cells and incubated for $216 \mathrm{~h}$. BTE showed cytotoxic effects against all carcinoma cell lines, however HT-29 and MCF-7 cells were more sensitive than A549. BTE showed no antiproliferative effect against healthy cells NIH-3T3 at tested concentrations. We found no apoptotic cell death in HT-29 and MCF-7 cells after $72 \mathrm{~h}$ of incubation in case of single administration of BTE but in case of repetitive administration of BTE (BTE was added to the cells each day) we found apoptotic cell death in HT-29 after $72 \mathrm{~h}$ incubation. BTE induced also DNA strand breaks and oxidative damage to DNA in carcinoma cells HT-29 and MCF-7.
\end{abstract}

Keywords: Camellia sinensis; Black tea; Cancer; Protective effect; Apoptosis

\section{Introduction}

Black tea has a long history of use dating back to China approximately 5,000 years ago. It is made from the dried leaves of Camellia sinensis, a perennial evergreen shrub formerly known as Thea sinensis. It is native to southeastern Asia. Green tea, black tea, and oolong tea are all derived from the same plant. Black tea results from the oxidation of Camellia sinensis leaves. The chemical components in tea include alkaloids (theobromine, caffeine, theophylline), polyphenols, amino acids, polysaccharides, volatile acids, vitamins, lipids as well as inorganic elements (Liang et al. 2013; Xiaorong et al. 2015; Scoparo et al. 2014). Black tea is used for treating headaches, low blood pressure, preventing heart disease, including atherosclerosis and heart attack, preventing Parkinson's disease, reducing the risk of stomach and colon cancer, lung, ovarian and breast cancers (Lee and Foo 2013). The aim of our study was to evaluate the potential anticancerogenic effect of the black tea extract (BTE) on different types of carcinoma cell lines.

\footnotetext{
* Correspondence: ingrid.zitnanova@fmed.uniba.sk

${ }^{1}$ Institute of Medical Chemistry, Biochemistry and Clinical Biochemistry, Faculty of Medicine, Comenius University, Sasinkova 2, 81108 Bratislava, Slovak Republic

Full list of author information is available at the end of the article
}

\section{Results}

Antiproliferative effects of BTE - single administration of BTE

BTE showed the highest cytotoxic effect against HT-29 (human colon carcinoma cell line) cells after $24 \mathrm{~h}$ of influence (Table 1). $\mathrm{IC}_{50}$ was lower than the lowest concentration used $(0.00078 \mu \mathrm{g} / \mathrm{mL})$ and stayed unchanged during the next $24 \mathrm{~h}$. On the third day of incubation $\mathrm{IC}_{50}$ slightly increased. Similar pattern with higher $\mathrm{IC}_{50}$ concentrations can be observed in MCF-7 (human breast carcinoma cell line) cells. The least sensitive cells towards BTE were cells A549 (human adenocarcinoma alveolar cell line). We observed no antiproliferative effects of BTE on mouse healthy fibroblast cell line NIH-3T3 during $72 \mathrm{~h}$ of influence at BTE concentrations $0.00078-5 \mu \mathrm{g} / \mathrm{mL}$.

Cytotoxic effects of BTE - repetitive administration of BTE Because HT-29 cells were the most sensitive to the extract we have performed further studies to determine its cytotoxic effect on HT-29 cells after repetitive administration of BTE during $216 \mathrm{~h}$ incubation. We added BTE to the cells every $24 \mathrm{~h}$ (repetitive administration of BTE) during the first 3-days of incubation and then every

\section{穴}


Table 1 Cytotoxic/antiproliferative effect of BTE against HT-29, MCF-7, A549 and NIH-3T3 cell lines represented by IC ${ }_{50}$ $(\mu \mathrm{g} / \mathrm{mL})$

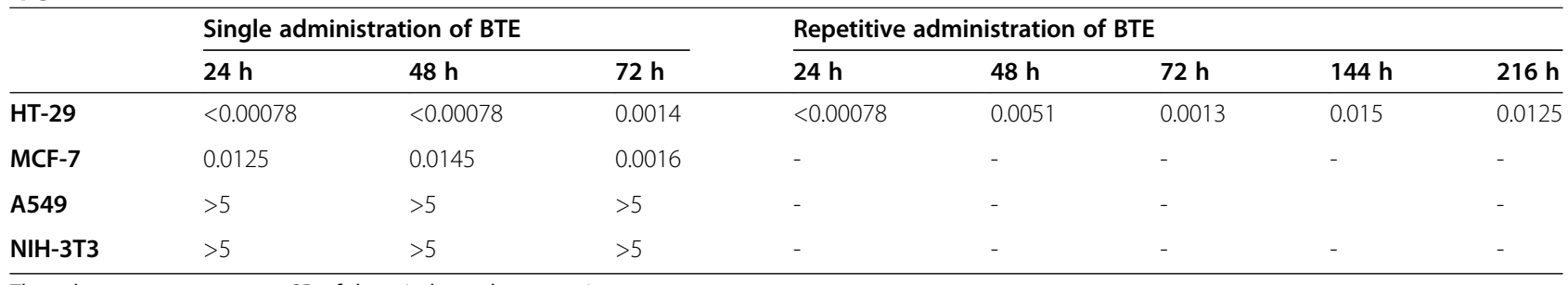

The values represent mean \pm SD of three independent experiments.

$72 \mathrm{~h}$ and we counted cells at the same time points. We found no significant difference between $\mathrm{IC}_{50}$ during single BTE administration and repetitive administration. With increasing time of incubation cells became more resistant to the administered BTE extract.

\section{Type of cells death induced by BTE}

Analysis of DNA fragmentation was performed using conventional agarose gel electrophoresis to distinguish between apoptotic cell death and other types of cell death. Cells were exposed to single administration of BTE (0.00625 $5 \mu \mathrm{g} / \mathrm{mL}$ ) for $72 \mathrm{~h}$ and repetitive administration of BTE for $216 \mathrm{~h}$ of incubation. In cells HT-29 we observed no apoptotic cell death during single administration of BTE but we detected apoptosis during repetitive administration of BTE after 144 and $216 \mathrm{~h}$ of influence (Figure $1 \mathrm{a}, \mathrm{b}$ ).

In MCF-7 cells no apoptotic cell death was detected during single and repetitive administration of BTE (Figure $1 \mathrm{c}, \mathrm{d}$ ).

\section{Genotoxic effect}

We examined the DNA damage induced by BTE $(0.00078-5 \mu \mathrm{g} / \mathrm{mL})$ after $24 \mathrm{~h}$ of incubation. Induction of DNA strand breaks (without Fpg) and total DNA damage (with Fpg) was dose independent in both cell lines (Figure 2a,b) and percentage of DNA strand breaks was approximately the same for each concentration used (up to $55 \%$ of DNA damage). Level of total DNA damage was higher (up to $60 \%$ ). HT-29 cells were less sensitive to DNA damage compared with MCF-7 cells.

\section{Detection of hydrogen peroxide levels}

We have determined levels of hydrogen peroxide in the culture medium of cells incubated with BTE extract $\left(\mathrm{IC}_{50}\right)$ for up to 72 hours. At the BTE concentrations used in our experiment we have not detected any production of hydrogen peroxide in the medium. We repeated our experiments with addition of catalase $(50 \mathrm{U} / \mathrm{mL})$ to the cancer cells during $72 \mathrm{~h}$ of incubation with BTE extract and we did not detect any changes of hydrogen peroxide levels with or without addition of catalase.

\section{Discussion}

White tea, yellow tea, green tea, oolong, pu-erh tea and black tea are all harvested from the same species Camellia sinensis, but are processed differently to attain different levels of oxidation. Fermentation of crushed tea leaves results in the production of the black tea. This process is characterized by enzymatic oxidation and condensation of polyphenolic compounds generating oligomeric (theaflavins) and polymeric (thearubigins) polyphenols (Ju et al. 2007). Their beneficial effects on health are ascribed to their antioxidant and biomodulating properties. It has been reported that theaflavins are able to inhibit certain types of cancer (Kosińska and Andlauer 2004; Tu et al. 2004; Kundu et al. 2005; Ju et al. 2007; Dvořáková et al. 2010; John et al. 2014; Korir et al. 2014).

In this study we have investigated cytotoxic/antiproliferative effects of BTE from Camellia sinensis on different types of carcinoma cell lines (HT-29, MCF-7, A549) and compared with effects on the healthy cell line NIH-3T3. We have found dose- and time-dependent cytotoxic effects against the carcinoma cell lines. The cell lines HT-29 (colon cancer) and MCF-7 (breast cancer) were more sensitive to the extract than A549 (lung cancer) after $72 \mathrm{~h}$ of cultivation. The effect of BTE on healthy cells NIH-3T3 was milder. Growth inhibitory activities of BTE in cancer cells were observed also in other studies (Sharangi 2009; Miloševič et al. 2013) with effects depending on the cell type and concentrations used.

We have studied induction of apoptosis by BTE using DNA fragmentation assay. Cells exposed to BTE exhibited characteristic internucleosomal DNA fragmentation. We used single and repetitive administrations of BTE to carcinoma cell lines HT-29 and MCF-7. We have detected apoptosis only in cells HT-29 during repetitive administration of BTE. Single BTE administration did not result in apoptosis either in HT-29 or in MCF-7 cancer cells. Contrary to our results, Yang et al. (Yang et al. 1998) found apoptosis in HT-29 cells exposed to theaflavins for $24 \mathrm{~h}$. They determined apoptosis by the annexin $\mathrm{V}$ apoptosis assay. Several other studies have shown that Camellia sinensis extract induced apoptosis in cancer cell lines (Yang et al. 1998; Sun et al. 2013; Brizuela and Cuvillier 2014; Wanga et al. 2014). However, they used either 


\section{a}
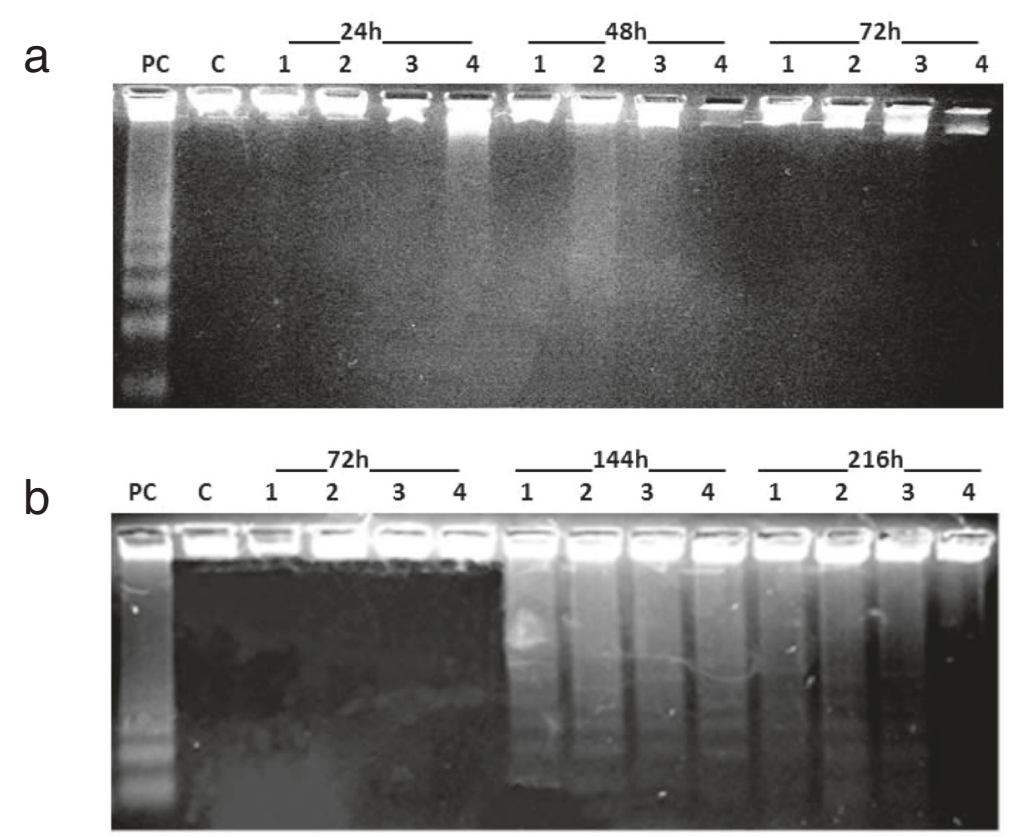

C
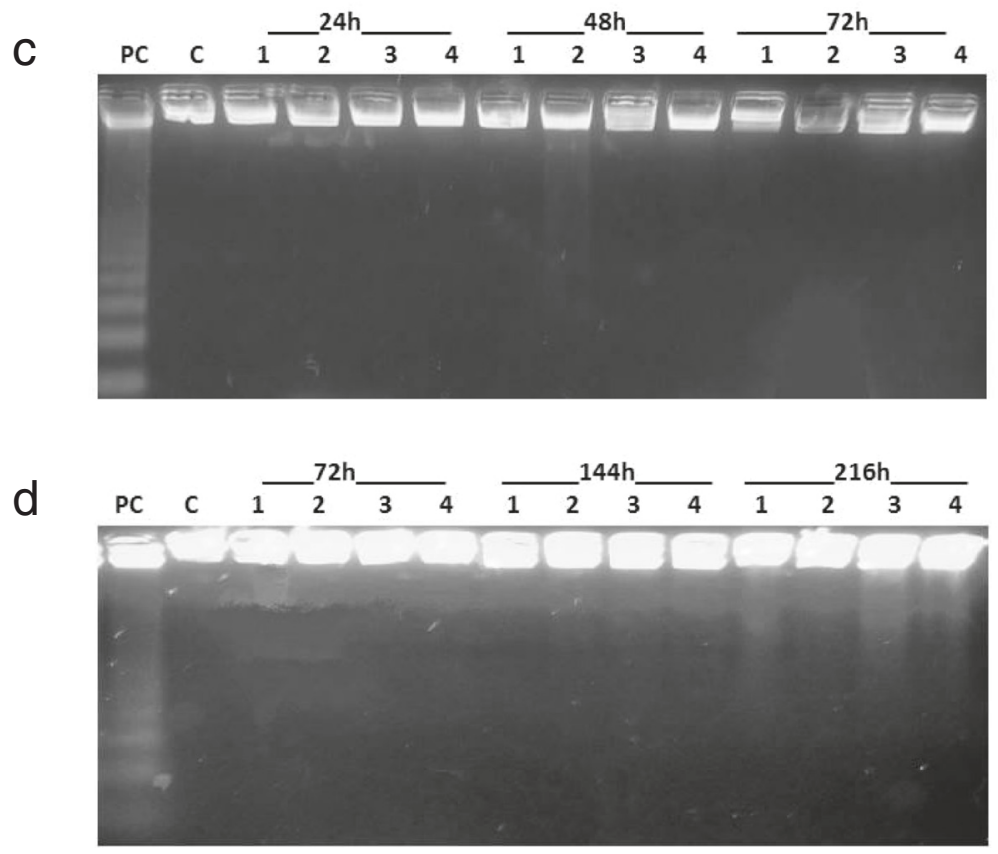

Figure 1 Agarose gel electrophoresis in cells HT-29 (a, b) and MCF-7 (c, d) treated with 1-0.00625 $\mu \mathrm{g} / \mathrm{mL} ; 2-0.0125 \mu \mathrm{g} / \mathrm{mL} ; 3-0.025 \mu \mathrm{g} / \mathrm{mL}$;

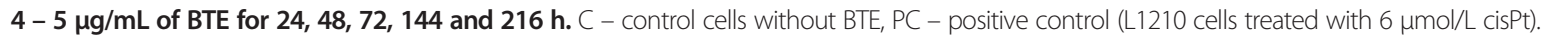

much higher concentrations (more than 20x) of the BTE than we did, or different carcinoma cell lines. Prasad et al. (Prasad et al. 2007) studied the mechanism of theaflavins' action on cellular proliferation and cell death in the human prostate cancer cell line PC-3. They found that theaflavins act as anti-proliferative agents by modulating cell growth regulators in prostate cancer cells.

In our study we have detected genotoxic effects of BTE on human carcinoma cell lines (HT-29 and MCF-7) after $24 \mathrm{~h}$ cultivation but this effect was dose independent. Similar results were reported also in other studies (Saha and Das 2002; Prasad et al. 2007; Halder et al. 2008; Nagini and Murugan 2013; Forbes-Hernández et al. 2014; Hajiaghaalipour et al. 2015). Polyphenolic compounds in the tea are considered strong antioxidants preventing tumor development through its antioxidant function (Feng et al. 2002; Higdon and Frei 2003). However, results of our study indicate that at high concentrations bioactive 

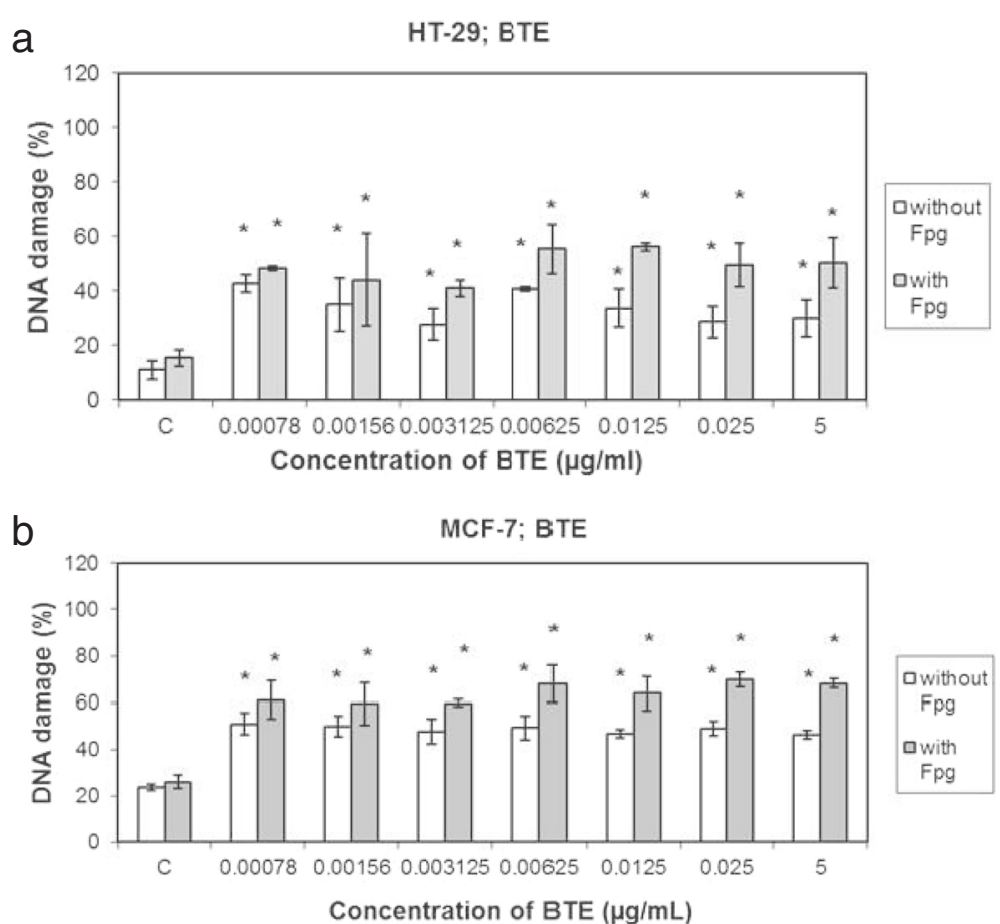

Figure 2 Effects of BTE on the DNA damage (\%) in HT-29 (a) and MCF-7 (b) cells after $\mathbf{2 4} \mathbf{h}$ treatment. DNA damage was represented by DNA strand breaks (without Fpg) and as the total DNA damage (with Fpg). Each value represents the arithmetic mean \pm SD of three separate experiments $(n=3):{ }^{*}<0.05$ when compared with controls (HT-29 or MCF-7 cells without BTE). Maximal DNA damage (100\%) for 100 comets was considered the DNA damage (TD) with the maximal score (400).

compounds in the BTE are themselves capable of oxidative damage to DNA in cancer cells probably through their pro-oxidant action. Polyphenolic compounds are redoxsensitive compounds able to reduce redox active metal ions $\left(\mathrm{Fe}^{3+}, \mathrm{Cu}^{2+}\right)$ which can then catalyze formation of reactive hydroxyl radical $(\mathrm{OH})$ through the Fenton type reaction (Hadi et al. 2000; Malik et al. 2003; Forester and Lambert 2014; Tao and Lambert 2014).

\section{Conclusion}

Our results confirmed that BTE possess potent antiproliferative and genotoxic properties against human colon carcinoma and human breast cancer cell line. Our findings indicate that BTE has the potential to become a safe therapeutic anti-carcinogenic agent. However, to support the hypothesis that black tea extract might play a role in the cancer prevention, some randomized controlled trials as well as large prospective cohort studies are needed.

\section{Materials and methods}

\section{Chemicals}

Normal melting point agarose (NMP agarose), Triton-X 100 , ethidium bromide (EtBr), RNase, proteinase $\mathrm{K}$, phosphate-buffered saline (PBSa), all culture media, fetal calf serum, antibiotics, catalase and Fpg enzyme were purchased from Sigma Aldrich (Slovakia). Low melting point agarose (LMP) was purchased from Invitrogen (Great Britain). Ethylenediaminetetraacetic acid (EDTA), ethylenediaminetetraacetic acid disodium salt $\left(\mathrm{Na}_{2} \mathrm{EDTA}\right)$, and sodium hydroxide $(\mathrm{NaOH})$ were obtained from Lachema (Brno, Czech Republic). Kit OxiSelect ${ }^{\mathrm{Tw}}$ hydrogen peroxide assay kit, Colorimetric was obtained from Cell Biolabs, Inc. (USA).

\section{Black tea extract}

Extract from Camellia sinensis (black tea) (BTE) was kindly provided by Dipl. Ing. Ján Keresteš (Molecule of Life Ltd., Senec, Slovakia). The extract is water soluble. It contains active flavonoids min. $96 \%$ such as catechins (60 - 75\%), leukoantocyanidins (25 - 40\%), cyanidins and general flavone derivatives of diols. The complexes of flavonoids are present in mono and oligomeric form.

\section{Cell cultures}

Human colon carcinoma cells (HT-29), adenocarcinoma human alveolar basal epithelial cells (A549), breast carcinoma cell line (MCF-7) and mouse embryonic fibroblast healthy cell line (NIH-3T3) were purchased from American Type Culture Collection (ATCC), Rockville, MD, USA. All cell lines were maintained in complete Dulbecco's Modified Eagle's Medium supplemented with 10\% (vol./vol.) fetal calf serum, penicillin G $(100 \mu \mathrm{g} / \mathrm{mL})$ and 
streptomycin $(100 \mu \mathrm{g} / \mathrm{mL})$. All cell lines were grown at $37^{\circ} \mathrm{C}$ in humidified $5 \% \mathrm{CO}_{2}$ and $95 \%$ air atmosphere. The HT-29 cells were plated on the Petri dishes (diameter $60 \mathrm{~mm}$ ) at a density of $1.5 \times 10^{5}$ cells per mL, MCF-7 and A549 at a density of $8 \times 10^{4}$ cells per mL and NIH-3 T3 at a density of $6.0 \times 10^{4}$ cells per mL of medium. All cell lines were incubated for $24 \mathrm{~h}$ prior to experiments.

\section{Antiproliferative/cytotoxic effect}

Cell proliferation, growth curves, cell viability and cytotoxic potential of BTE (Molecule of Life, Ltd., Senec, Slovakia) was determined by the MTT test and the trypan blue dye exclusion test. MTT test is based on the reduction of yellow soluble compound 3-[4,5-dimethylthiazol-2-yl]2,5-diphenyl tetrazolium bromide (MTT, Sigma-Aldrich Chemical, Taufkirchen, Germany) into an insoluble formazan (blue star-shaped crystals). The reaction takes place in the mitochondrial membrane of living cells. Formazan was dissolved by addition of a strong detergent and color was read spectrophotometrically at a wavelength of $540 \mathrm{~nm}$. Absorbance of the solution is proportional to the number of living cells. Before reading absorbances we washed cells with PBS thus removing the interference of the polyphenols with MTT assay. By the trypan blue dye exclusion test the cell proliferation was determined by direct counting of cells in a counting chamber.

For the 3 day experiments cells A549, HT-29, MCF-7 and NIH-3T3 were seeded in $60 \mathrm{~mm}$ Petri dishes and after $24 \mathrm{~h}$ of incubation at $37^{\circ} \mathrm{C}$ the cells were/were not exposed to BTE for 24, 48, 72, 144 and $216 \mathrm{~h}$. Growth curves, cytotoxic/antiproliferative effects and inhibitory concentrations $\mathrm{IC}_{50}$ (the median concentration that causes $50 \%$ inhibition of growth) were determined. All tests were performed three times. Final concentrations of BTE added to the cells were within the concentration range $0.00078-5000 \mu \mathrm{g} / \mathrm{mL}$.

\section{Electrophoretic analysis}

Control cells (without BTE) HT-29, MCF-7 and cells treated with BTE (final concentration of BTE was from 0.00625 to $5 \mu \mathrm{g} / \mathrm{L}$ ) were incubated for $24,48,72,144$ and $216 \mathrm{~h}$ then harvested, washed with PBS, and then lysed in $50 \mu \mathrm{L}$ of lysing solution $(10 \mathrm{mmol} / \mathrm{L}$ Tris, $10 \mathrm{mmol} / \mathrm{L}$ EDTA, 0.5\% Triton X-100) supplemented with proteinase $\mathrm{K}(1 \mathrm{mg} / \mathrm{mL})$. Samples were then incubated at $37^{\circ} \mathrm{C}$ for $1 \mathrm{~h}$ and heated at $70^{\circ} \mathrm{C}$ for $10 \mathrm{~min}$. Following lysis, RNase $(200 \mu \mathrm{g} / \mathrm{mL})$ was added and incubated at $37^{\circ} \mathrm{C}$ for $1 \mathrm{~h}$. The cell lysates were loaded into $2 \%$ agarose gel, stained with ethidium bromide $(1 \mathrm{mg} / \mathrm{mL})$ and subjected to electrophoresis $(40 \mathrm{~V}, 3 \mathrm{~h}$ ). Separated DNA fragments (DNA ladders) were visualised on a UV transilluminator (254 nm, Ultra-Lum Electronic UV Transilluminator, USA).

\section{Comet assay}

DNA strand breaks and oxidative DNA damage were measured using the alkaline comet assay (Collins et al. 1993). Cells were resuspended in $400 \mu \mathrm{L}$ of $0.8 \%$ low melting point agarose in $\mathrm{PBS}$ at $37^{\circ} \mathrm{C}$ and pipetted onto a frosted microscope slide precoated with $100 \mu \mathrm{L}$ of $1 \%$ normal melting point agarose. Slides with layers of cells in agarose were incubated in a refrigerator for $10 \mathrm{~min}$ $\left(4^{\circ} \mathrm{C}\right)$, then immersed in lysis solution $(2.5 \mathrm{~mol} / \mathrm{L} \mathrm{NaCl}$, $100 \mathrm{mmol} / \mathrm{L}, \mathrm{Na}_{2} \mathrm{EDTA}, 10 \mathrm{mmol} / \mathrm{L}$ Tris, $1 \%$ Triton, $\mathrm{pH} 10$ ) for $1 \mathrm{~h}$ to remove cell membranes. After lysis, slides were placed in a horizontal electrophoresis tank containing electrophoresis solution $\left(1 \mathrm{mmol} / \mathrm{L} \mathrm{Na}_{2}\right.$ EDTA, $300 \mathrm{mmol} / \mathrm{L} \mathrm{NaOH}, \mathrm{pH} 13$ ) at $4^{\circ} \mathrm{C}$ for $40 \mathrm{~min}$ (DNA uncoiling). Electrophoresis was performed in the same solution at $25 \mathrm{~V}, 300 \mathrm{~mA}, 4^{\circ} \mathrm{C}$, for $30 \mathrm{~min}$. The slides were washed three times for $5 \mathrm{~min}$ at $4^{\circ} \mathrm{C}$ with neutralising buffer $(0.4 \mathrm{mmol} / \mathrm{L}$ Tris, $\mathrm{pH}$ 7.5) before staining with $20 \mu \mathrm{L}$ of 4,6-diamidine-2-phenylindole dihydrochlorid (DAPI, $1 \mu \mathrm{g} / \mathrm{mL}$ solution in distilled water). To detect total DNA damage (DNA strand breaks and oxidative DNA damage) we used formamidopyrimidine DNA glycosylase enzyme (Fpg). Comets were viewed by fluorescence microscopy after staining with DAPI. The intensity of the comet tail relative to the head reflects the number of DNA breaks by manual scoring. One hundred cells from each of two replicate slides were analyzed for each BTE concentration and classified into five classes according to the relative intensity of fluorescence in the tail and given a value of 0-4 (from undamaged 0 , to maximally damaged 4). The total score for 100 comets could range, therefore, from 0 (all undamaged) to 400 (all maximally damaged).

Total DNAdamage (TD) was obtained by summation (Collins et al. 1993; Collins et al. 1997):

$$
\mathrm{TD}=\sum_{\mathrm{i}=0}^{4} \mathrm{i} . \mathrm{N}_{\mathrm{i}}
$$

Where $\mathrm{i}$ - class of damage, $\mathrm{N}$ - number of cells in the class

We calculated \% of DNA damage according to the formula:

$$
\text { DNA damage }(\%)=(\mathrm{TD} / 400) * 100
$$

\section{Detection of hydrogen peroxide levels}

Hydrogen peroxide levels in medium of cells incubated with our BTE extract with/without addition of catalase $(50 \mathrm{U} / \mathrm{mL})$ for up to 72 hours were detected by the OxiSelect ${ }^{\mathrm{mi}}$ hydrogen peroxide assay kit, Colorimetric, Cell Biolabs, Inc. As a possitive control we used the sample with hydrogene peroxide $(0.8 \mu \mathrm{mol} / \mathrm{L})$ added in the medium. 


\section{Statistical analysis}

Results are expressed as arithmetic means \pm standard deviation (SD) of the means of three separate experiments (each experiment was done with three parallels).

The statistical evaluation was performed using parametric unpaired $t$-test. A difference at $\mathrm{P}<0.05$ was considered statistically significant.

\section{Abbreviations}

BTE: Black tea extract; DAPI: 4',6-diamidine-2-phenylindole dihydrochlorid; Fpg: Formamidopyrimidine DNA glycosylase; $I_{50}$ : Half maximal inhibitory concentration; PBS: Phosphate-buffered saline; PC: Positive control; TD: Total DNA damage.

\section{Competing interests}

The authors declare that they have no competing interests.

\section{Authors' contributions}

KK carried out MTT test and electrophoresis, KK and MJ performed comet assay; HG performed detection of hydrogen peroxide levels; KK, JK, ZD and IZ participated in the design of the study and wrote the manuscript. All authors read and approved the final manuscript.

\section{Acknowledgement}

This project was supported by the NIKA (Považská Bystrica, Slovakia) and VEGA grant 1/0752/13.

\section{Author details}

${ }^{1}$ Institute of Medical Chemistry, Biochemistry and Clinical Biochemistry, Faculty of Medicine, Comenius University, Sasinkova 2, 81108 Bratislava, Slovak Republic. ${ }^{2}$ Molecule of Life, Ltd, Lichnerova 38, 90301 Senec, Slovakia. ${ }^{3}$ Institute of Medical Biology, Genetics and Clinical Genetics, Comenius University, Sasinkova 4, 81108 Bratislava, Slovak Republic.

\section{Received: 17 July 2014 Accepted: 3 February 2015}

\section{Published online: 14 March 2015}

\section{References}

Brizuela L, Cuvillier O (2014) Polyphenols in Human Health and Disease. In: Brizuela L (ed) Polyphenols in Prostate Cancer, vol 1. Academic press, London, pp 1217-1230

Collins AR, Dusinska M, Gedik CM, Stetina R (1993) Oxidative damage to DNA: do we have a reliable biomarker? Carcinog 14:1733-1735

Collins AR, Dobson VL, Dusinska M, Kennedy G, Stetina R (1997) Comet assay: What can it really tell us? Mutat Res 375:183-193

Dvořáková M, Paduchová Z, Muchová J, Duračková Z, Collins AR (2010) How does pycnogenol ${ }^{\oplus}$ influence oxidative damage to DNA and its repair ability in elderly people? Prague Med Rep 111(4):263-271

Feng Q, Torii Y, Uchida K, Nakamura Y, Hara Y, Osawa T (2002) Black tea polyphenols, theaflavins, prevent cellular DNA damage by inhibiting oxidative stress and suppressing cytochrome P450 1A1 in cell cultures. J Agric Food Chem 50(1):213-222

Forbes-Hernández TY, Giampieri F, Gasparrini M, Mazzoni L, Quiles JL, Alvarez-Suarez JM Battino M (2014) The effects of bioactive compounds from plant foods on mitochondrial function: A focus on apoptotic mechanisms. Food Chem Toxic 82:154-182

Forester SC, Lambert JD (2014) Polyphenols in Human Health and Disease. In: Forester S (ed) Cancer Preventive Effects of Green Tea Polyphenols, vol 1. Academic press, London, pp 1309-1322

Hadi SM, Asad SF, Singh S, Ahmad A (2000) Putative mechanism for anticancer and apoptosis - inducing properties of plant - derived polyphenolic compounds. IUBMB Life 50(3):167-171

Hajiaghaalipour F, Kanthimathi MS, Sanusi J, Rajarajeswaran J (2015) White tea (Camellia sinensis) inhibits proliferation of the colon cancer cell line, HT-29, activates caspases and protects DNA of normal cells against oxidative damage. Food Chem 169:401-410

Halder B, Bhattacharya U, Mukhopadhyay S, Giri AK (2008) Molecular mechanism of black tea polyphenols induced apoptosis in human skin cancer cells: involvement of Bax translocation and mitochondria mediated death cascade. Carcinog 29(1):129-138

Higdon JV, Frei B (2003) Tea catechins and polyphenols: health effects, metabolism, and antioxidant functions. Crit Rev Food Sci Nutr 43:89-143

John KM, Thiruvengadam M, Enkhtaivan G, Kim DH (2014) Variation in major phenolic compounds and quality potential of CTC black tea elicited by Saccharomyces cercevisiae and its correlation with antioxidant potential. Ind Crops Prod 53:289-294

Ju J, Lu G, Lambert JD, Yang CS (2007) Inhibition of carcinogenesis by tea constituents. Semin Cancer Biol 17:395-402

Korir MW, Wachira FN, Wanyoko JK, Ngure RM, Khalid R (2014) The fortification of tea with sweeteners and milk and its effect on in vitro antioxidant potential of tea product and glutathione levels in an animal model. Food Chem 145:145-153

Kosińska A, Andlauer W (2004) Effect of Processing and Storage. Processing and Impact on Antioxidants in Beverages. Antioxidant Capacity of Tea. doi:10.1016/B978-0-12-404738-9.00012-X

Kundu T, Dey S, Roy M, Siddiqi M, Bhattacharya RK (2005) Induction of apoptosis in human leukemia cells by black tea and its polyphenol theaflavin. Cancer Lett 13:111-121

Lee LK, Foo KY (2013) Recent advances on the beneficial use and health implications of Pu-Erh tea. Food Res Int 53(2):619-628

Liang Y, Lu J, Zhang L, Wu S, Wu Y (2013) Estimation of black tea quality by analysis of chemical composition and colour difference of tea infusions. Food Chem 80(2):283-290

Malik A, Azam S, Hadi N, Hadi SM (2003) DNA degradation by water extract of green tea in the presence of copper ions: Implications for anticancer properties. Phytother Res 17:358-363

Miloševič CD, Tambur Z, Ivančajic S, Bokonjic D, Čukovic A, Stanojkovic T (2013) Antiproliferative effects of Camellia sinensis, Frangula alnus and Rosmarinus officinalis. Arch Biol Sci Belegrade 65(3):885-891

Nagini S, Murugan RS (2013) Tea Health Disease Prev. In: Nagini S (ed) Cancer Chemoprevention by Black Tea Polyphenols: Emerging Evidence and Molecular Targets. Academic press, London, pp 737-750

Prasad S, Kaur J, Roy P, Kalra N, Shukla Y (2007) Theaflavins induce G2/M arrest by modulating expression of $\mathrm{p} 21^{\text {waf1/cip } 1}, \mathrm{cdc} 25 \mathrm{C}$ and cyclin B in human prostate carcinoma PC-3 cells. Life Sci 81(17,18):1323-1331

Saha P, Das S (2002) Elimination of deleterious effects of free radicals in murine skin carcinogenesis by black tea infusion, theaflavins \& epigallocatechin gallate. Asian Pac J Cancer Prev 3(3):225-230

Scoparo CT, Borato DG, Souza LM, Dartora N, Silva SM, Ferreira DM, Sassaki GL, Gorin P, Baggio CH, lacominia M (2014) Gastroprotective bio-guiding fractionation of hydro-alcoholic extracts from green- and black-teas (Camellia sinensis). Food Res Inter 64:577-586

Sharangi AB (2009) Medicinal and therapeutic potentialities of tea (Camellia sinensis L.)-A review. Food Res Int 42(5-6):529-535

Sun S, Pan S, Miao A, Ling C, Pang S, Tang J (2013) Active extracts of black tea (Camellia Sinensis) induce apoptosis of PC-3 prostate cancer cells via mitochondrial dysfunction. Oncol rep 30(2):763-772

Tao L, Lambert JD (2014) Polyphenols in Human Health and Disease. In: Tao L (ed) Antioxidant and Pro-Oxidant Activities of Green Tea Polyphenols in Cancer Prevention, vol 1. Academic press, London, pp 1191-1198

Tu YY, Tang AB, Watanabe N (2004) The theaflavin monomers inhibit the cancer cells growth in vitro. Acta Biochim Biophys Sin 36(7):508-512

Wanga P, Vadgama JV, Said JW, Magyar CE, Doan N, Heber D, Henning SM (2014) Enhanced inhibition of prostate cancer xenograft tumor growth by combining quercetin and green tea. J Nutr Biochem 25(1):73-80

Xiaorong L, Zhongzheng C, Yuanyuan Z, Wei L, Hao T, Baibiao D, Jian D, Bin L (2015) Comparative characterisation of green tea and black tea cream: Physicochemical and phytochemical nature. Food Chem 173:432-440

Yang G, Liao J, Kim K, Yurkow EJ, Yang CS (1998) Inhibition of growth and induction of apoptosis in human cancer cell lines by tea polyphenols. Carcinog 19(4):611-616 